\title{
Penggunaan Metode Kooperatif Model Artikulasi Terhadap Upaya Peningkatan Hasil Belajar Siswa pada Mata Pelajaran PKn Kelas VII SMPN 2 Gangga Kabupaten Lombok Utara
}

\author{
Achmad Djunaidi' ${ }^{1}$ Taufik ${ }^{2}$ \\ ${ }^{1}$ Pendidikan Pancasila dan Kewarganegaraan, Universitas Muhammadiyah Mataram, Email: djuanidiachmad@gmail.com \\ ${ }^{2}$ Pendidikan Pancasila dan Kewarganegaraan, Universitas Muhammadiyah Mataram, Email: taufik12@gmail.com
}

\begin{abstract}
INFO ARTIKEL
Riwayat Artikel:

Diterima: 10-Maret-

2019

Disetujui: 20-Maret2019
\end{abstract}

\section{Kata Kunci:}

kooperatif

model

artikulasi

hasil belajar

\begin{abstract}
ABSTRAK
Abstrak:: Rendahnya kemampuan mengemukakan pendapat siswa Pada Mata Pelajaran Pendidikan Kewarganegaraan. Penelitian ini bertujuan untuk mengetahui apakah penerapan metode pembelajaran Kooperatif Model Artikulasi dapat meningkatkan Hasil Belajar Siswa Pada Mata Pelajaran PKn Kelas VII SMP N 2 Gangga. Sampel dalam penelitian ini adalah siswa kelas VII SMPN 2 Gangga sebanyak 24 orang, yang terdiri dari 14 siswa laki-laki dan 10 siswa perempuan. Jenis penelitian menngunakan eksperimen dengan pendekatan kuantitatif desain Pre-test dan Post-est. Desain ini digunakan sebelum eksperimen dan sesudah eksperimen. Sedangkan analisis yang digunakan adalah analisis statistik dengan rumus t-tes. Hasil penelitian menunjukkan bahwa t-hitung sebesar 12,64 dari t-tabel 2,069 yang berarti terdapat pengaruh signifikan dengan menggunakan metode pembelajaran Kooperatif model Artikulasi terhadap proses belajar mengajar. Rata-rata hasi belajar siswa yang dikenakan metode pembelajaran Kooperatif model Artikulasi sebesar 77,67 dan hasil belajar siswa yang tidak dikenakan perlakuan sebesar 67,67. Dengan demikian disimpulkan bahwa penerapan metode pembelajaran Kooperatif model artikulasi dapat meningkatkan hasil belajar PKn siswa kelas VII di SMPN 2 Gangga, maka dapat dikatakan hipotesis ( $\mathrm{Ha}$ ) diterima yang berbunyi bahwa metode pembelajaran Kooperatif model Artikulasi dapat meningkatkan kualitas hasil belajar PKn siswa.
\end{abstract}

\begin{abstract}
The low ability to express student opinions in the Subject of Citizenship Education. This study aims to determine whether the application of Cooperative learning methods Articulation Model can improve Student Learning Outcomes in Class VII Civics Subjects of Ganges N 2 Middle School. The sample in this study were class VII students of Ganges 2 Junior High School as many as 24 people, consisting of 14 male students and ten female students. This type of research uses experiments with a quantitative approach to Pre-test and Post-test design. This design was used before the trial and after the test. While the analysis used is statistical analysis using the t-test formula. The results showed that $t$-count was 12.64 from t-table 2.069, which means that there was a significant effect using the Cooperative learning method of the Articulation model on the teaching and learning process. The average student learning outcomes subject to the Cooperative learning method of Articulation model is 77.67, and student learning outcomes that are not subject to treatment amounted to 67.67. Thus it was concluded that the application of Cooperative learning methods articulation models could improve Citizenship Education learning outcomes of class VII students in Ganges 2 Ganga, it can be said the hypothesis (Ha) is accepted which means that Cooperative learning methods Articulation models can improve the quality of Citizenship Education student learning outcomes.
\end{abstract}

\section{A. LATAR BELAKANG}

Pembelajaran yang baik adalah pembelajaran yang berkualitas, kualitas pembelajaran yang baik akan mampu memberikan kompetensi kepada siswa dalam hal: (1) Berpikir secara kritis, rasional, dan kreatif, dalam menanggapi permasalahan, (2) Berpartisipasi secara aktif dan bertanggung jawab, dan bertindak secara cerdas dalam kegiatan bermasyarakat, berbangsa dan bernegara [1].
Ciri-ciri pembelajaran yang berkualitas dilihat dari segi psikologi adalah adanya perubahan kematangan bagi anak didik sebagai akibat belajar, contohnya seorang siswa yang tadinya tidak mengetahui apa-apa menjadi tahu, siswa yang semulanya kurang paham tentang sesuatu menjadi paham. Sedangkan dilihat dari proses adalah adanya interakasi antara peserta didik dengan pendidik sebagai proses pembelajaran, contohnya siswa berani mengemukakan pendapat pada 
saat proses pembelajaran berlangsung baik dengan diminta langsung oleh guru atau dengan inisiatip sendiri, siswa berani bertanya kepada guru tentang materi yang belum difahami. Perubahan kematan-gan ini akibat dari adanya proses pembelajaran, dan perubahan ini tampak pada perubahan tingkah laku yang dipengaruhi oleh ilmu pengetahuan yang diperolehnya dari proses belajar [2].

Untuk dapat menghasilkan pembelajaran yang berkualitas guru harus dapat membantu siswa dalam mengembangkan potensi yang dimilikinya, baik fungsi kognitif, afektif, maupun potensi psikomotorik agar menjadi warganegara yang memahami, mampu menyikapi dan berprilaku sesuai dengan hak dan kewajibannya sebagai warganegara. Pada dasarnya setiap siswa memiliki potensi yang berbeda yang harus terus digali dan dikembangkan, disinilah dibutuhkan peran seorang guru dalam mengarahkan dan membimbing siswa dalam mencapai kualitas pembelajaran yang baik. Hasil penelitian terdahulu menemukan hasil belajar diperoleh dari proses belajar siswa selama pembelajaran berlangsung, penilaian hasil tes akhir, dan Lembar Kerja Kelompok (LKK). Dari hasil belajar itu juga dapat digunakan untuk (1) menentukan nilai minimal, (2) penentu kenaikan kelas, (3) mendiagnosa permasalahan siswa dalam belajar, (4) mengetahui kemajuan belajar siswa, dan (5) memotivasi siswa[3]. Senada juga menjelaskan bahwa fakta saat pembelajaran berlangsung metode pembelajaran yang diterapkan kurang efektif untuk melatih kecakapan berkomunikasi siswa dan terlihat dari sedikitnya siswa yang bertanya, menjawab, dan berpendapat sehingga kedua hal tersebut mempengaruhi menurunya hasil belajar siswa yakni hanya mencapai $53,57 \%$ dari standard KKM Nilai <75 sementara yang tuntas mencapai 46,43\%[4]. Berbagai permasalahan yang diuraikan sebelumnya sejalan juga masalahnya di sekolah kabupaten Lombok Utara.

Berdasarkan hasil observasi awal yang dilakukan peneliti menemukan bahwa ada beberapa hal terakit dengan hasil belajar siswa masih tergolong rendah. rendahnya hasil belajar siswa dapat dilihat selama proses pembelajaran berlangsung, interaksi antara guru dengan siswa dan siswa dengan siswa dalam kelas rendah, sebagian besar siswa diam ketika guru memberikan kesempatan bertanya, siswa tidak memperhatikan penjelasan guru, dan catatan siswa kurang lengkap. Rendahnya hasil belajar siswa tersebut dapat dilihat dari sebagian siswa yang tidak mampu menjawab pertanyaan guru baik dalam proses pembelajaran maupun pada tes ujian tertulis. Nilai ratarata yang diperoleh siswa hanya mencapai 66 masih dibawah target KKM yaitu 70.

Proses pembelajaran dikatakan berhasil apabila terjadi perubahan perilaku yang positif pada diri peserta didik seluruhnya atau sekurang-kurangnya sebagian besar (75\%). Lebih lanjut proses pembelajaran dikatakan berhasil dan berkualitas apabila masukan merata, menghasilkan out put yang banyak, dan bermutu tinggi, serta sesuai dengan kebutuhan, perkembangan masyarakat dan pembangunan [5].

Masalah yang dihadapi siswa dalam proses pembelajaran tidak terlepas dari pengaruh metode pembelajaran yang digunakan oleh guru. Selama ini metode yang diterapkan oleh guru adalah metode diskusi dan metode ceramah. Diskusi dapat dilakukan di tengah atau di akhir kegiatan belajar mengajar dengan tujuan untuk mempertajam wawasan, memperjelas bahan atau menjawab pertanyaan. Dengan demikian masing-masing siswa dapat memperbaiki pengertian, persepsi, informasi, interpretasi, hingga menghindari kekeliruan-kekeli-ruan“ [6]. Dari penjelasan tersebut dalam diskusi tidak ada pembagian tugas yang jelas dan merata diantara anggota kelompok. Guru hanya memberikan tugas dan intruksi untuk mengerjakan secara bersama-sama. Siswa yang kurang memiliki rasa tanggung jawab terhadap tugas kelompoknya akan menyerahkannya pada siswa yang aktif. Dan adakalanya siswa tertentu akan merasa lebih bisa atau pintar sehingga tidak memberikan kesempatan pada yang lain untuk berkontribusi mengembang-kan pikirannya. Dalam hal ini tentu akan ada perbedaan pemahaman dan hasil belajar terhadap materi pelajaran diantara siswa yang aktif mengerjakan tugas dan siswa yang tidak menger-jakan tugas.

Hasil belajar dapat dimaknai sebagai perubahan tingkah laku yang diperoleh dari proses pembelajaran baik dalam aspek kognitif, afektif, dan psikomotorik. Pembelajaran yang baik adalah pembelajaran yang melibatkan siswa secara langsung dalam proses pembelajaran, dan salah satu langkah atau upaya yang dapat dilakukan untuk mengatasi rendahnya hasil belajar seperti yang telah terurai di atas, maka dilakukan upaya-upaya seperti membuat atau memilih metode pembelajaran yang lebih menarik atau bermakna [7].

Salah satu alternatif untuk meningkatkan hasil belajar siswa pada mata pelajaran PKn adalah dengan penerapan metode cooperatif model Artikulasi. Metode dan strategi belajar mengajar yang kondusif sangat perlu dikembangkan, karna dengan metode dan strategi tersebut diharapkan setiap peserta didik dapat mengembangkan diri dengan kebutuhan masyarakat apabila telah menyelesaikan suatu program pendidikan [5].

Pembelajaran model artikulasi merupakan model pembelajaran yang menuntut siswa aktif dalam pembelajaran siswa dibentuk menjadi kelompok kecil, masing-masing siswa dalam kelompok tersebut mempunyai tugas mewawa-ncarai teman kelompoknya tentang materi yang baru dibahas. Konsep pemahaman sangat diperlu-tkan dalam model pembelajaran ini [8]. model Artikulasi merupakan salah satu model 
pembelajaran yang melibatkan seluruh siswa dalam proses pembelajaran karena semua siswa akan terlibat (mendapat peran), melatih siswa untuk selalu siap dalam semua kondisi serta melatih daya serap pemahaman pelajaran dari orang lain. Dengan demikian siswa selalu mempersiapkan diri untuk menghadapi dan memikirkan yang terjadi pada dirinya.

Model Artikulasi prosesnya seperti pesan berantai, artinya apa yang telah diberikan Guru, seorang siswa wajib meneruskan menjelaskannya pada siswa lain (pasangan kelompoknya). Di sinilah keunikan model pembelajaran ini. Siswa dituntut untuk bisa berperan sebagai 'penerima pesan' sekaligus berperan sebagai 'penyampai pesan' [8]. Hasil penelitian menunjukkan bahwa penerapan model pembelajaran kooperatif tipe artikulasi dapat meningkatkan hasil belajar siswa[9]. Model artikulasi memberikan pengaruh yang positif dan bermakna dalam pembelajaran Pendidikan Kewarganegaraan[10].

Dengan demikian tujuan yang ingin diuraikan dalam artikel ini adalah untuk menjelaskan penggunaan metode cooperatif model artikulasi terhadap upaya peningkatan hasil belajar siswa pada mata pelajaran pkn kelas vii semester II SMP Negeri 2 Gangga Kabupaten Lombok Utara.

\section{B. METODE PENELITIAN}

\section{Metode Penelitian yang Digunakan}

Jenis penelitian dalam suatu unit penelitian bergantung dari gejala yang akan diteliti. Jika gejala yang diteliti itu telah ada secara wajar dilapangan maka digunakan metode empiris, sebaliknya jika gejala yang diteliti sengaja dibuat maka digunakan metode eksperimen [11]. Pendekatan yang digunakan dalam suatu penelitian pada umumnya dibagi menjadi dua yaitu pendekatan non eksperimen dan eksperimen. Yang dimaksud dengan pendekatan non eksperimen adalah suatu pendekatan yang digunakan dimana gejala yang diteliti telah ada secara wajar, sedangkan pendekatan eksperimen adalah suatu pendekatan yang dimana yang diteliti sengajas diadakan [7].

Dalam penelitian ini jenis metode yang digunakan adalah metode eksperimen. Eksperimen adalah suatu cara untuk mencari hubungan sebab akibat (hubungan kausal) antara dua faktor yang disengaja ditimbulkan oleh peneliti dengan mengurangi atau menyisihkan faktor-faktor yang mengganggu. Eksperimen dilakukan dengan maksud untuk melihat akibat dari suatu perlakuan [11].

Adapun bentuk eksperimen didalam melakukan suatu penelitian diantaranya:

a. Desain pre eksperimen (one shot case study, pra-tes pasca-tes atau satu kelompok, dan statis dua kelompok).

b. Desain true eksperimen (pasca-tes subjek acak dua kelompok. Pasca-tes subjek acak sepadan dua kelompok, prates-pascates kelompok acak). c. Desain quasi eksperimen (prates-pascates kelompok control tanpa acak) [12].

Dalam penelitian ini desaign yang digunakan adalah desaign pre-eksperimen dengan satu kelompok eksperimen. Rancangan penelitian yang digunakan adalah model one group pretes - posttes desaign. Kelas yang digunakan dalam penelitian ini adalah satu kelas.

Adapun desaign pre-eksperimen dengan model one group pre test-post test yakni:

Tabel 1

Model one group pre test-post test

\begin{tabular}{|c|c|c|}
\hline Pre test & Perlakuan & Post tes $t$ \\
\hline $\mathrm{O} 1$ & $\mathrm{X}$ & $\mathrm{O} 2$ \\
\hline
\end{tabular}

Keterangan : $\mathrm{O} 1=$ Pretes

$\mathrm{X}=$ Perlakuan

O2 = Posttes

\section{Subjek Penelitian}

\section{a. Populasi}

Populasi adalah keseluruhan subjek dalam penelitian [11]. Selain itu populasi juga dapat diartikan sebagai suatu himpunan yang terdiri dari orang, hewan, tumbuh-tumbuhan dan benda-benda yang mempunyai kesamaan sifat [13]. Populasi itu sendiri diterjemahkan sebagai sekelompok individu yang memiliki ilmu pengetahuan yang luas atau karakteristik umum yang menjadi pusat penelitian [14].

Dari pendapat beberapa para ahli diatas dapat disimpulkan bahwa populasi adalah semua keselu-ruhan objek, subjek, individu atau peristiwa lengkap, jelas dan diamati yang memiliki sifat-sifat yang sama serta memenuhi syarat-syarat tertentu dalam suatu penelitian.

Sehubungan dengan definisi populasi diatas, maka yang menjadi populasi penelitian ini adalah seluruh siswa kelas VII SMPN 2 Gangga yang berjumlah 99 orang siswa yang akan diuraikan pada tabel dibawah ini. Tabel 2

Data Keadaan Siswa kelas VII SMP N 2 Gangga Kabupaten Lombok Utara.

\begin{tabular}{cccc}
\hline \multirow{2}{*}{ Kelas } & \multicolumn{2}{c}{ Keadaan Siswa } & \multirow{2}{*}{ Jumlah } \\
& Laki-laki & Perempuan & \\
\hline VII A & 14 & 11 & 25 \\
VII B & 13 & 12 & 25 \\
VII C & 13 & 12 & 25 \\
VII D & 14 & 10 & 24 \\
\hline Jumlah & 54 & 45 & 99
\end{tabular}

\section{b. Sampel}

Sampel adalah adalah bagian dari jumlah dan karakteristik yang dimiliki oleh populasi tersebut [15]. Adapun sampel itu dapat dibatasi sebagai " proporsi yang lebih kecil dari populasi atau sampel adalah duplikat yang mencerminkan populasi" [16].

Sehubungan dengan definisi sampel diatas maka yang menjadi sampel penelitian ini adalah seluruh siswa kelas VII D yang berjumlah 24 siswa yang diruaikan pada table 5. Di bawah ini. 
Tabel 3

Data Keadaan Siswa kelas VII D SMPN 2 Gangga Kabupaten Lombok Utara

\begin{tabular}{ccc}
\hline \multicolumn{2}{c}{ Keadaan Siswa Kelas VII D } \\
Laki-laki $\quad$ Perempuan
\end{tabular}

14

10

24

Penentuan subjek penelitian diambil berdasar-kan teknik pengambilan data berdasarkan simple random sampling. Dikatakan simple (sederhana) karena pengambilan anggota sampel dari populasi dilakukan secara acak tanpa memperhatikan strata yang ada dalam populasi itu. Cara demikian dilakukan bila anggota populasi dianggap homogen [15].

\section{Teknik Pengumpulan Data}

Metode pengumpulan data adalah tehnik atau caracara yang digunakan oleh peneliti untuk mengumpulkan data. Metode menunjukan sesuatu kata yang abstrak dan tidak diwujudkan dalam suatu benda, tetapi hanya dilihat penggunaan melalui: wawasan, pengetahuan, ujian (tes), doku-mentasi dan lainnya [17].

Pengumpulan data adalah prosedur yang sistematik dan standar untuk memperoleh data yang diperlukan. Secara umum metode pengum-pulan data dapat dibagi atas beberapa kelompok, yaitu pengamatan langsung, metode dengan menggunakan pertanyaan-pertanyaan dan metode khusus [18].

Berdasarkan penelitian ini, maka data di kumpulkan dengan metode sebagai berikut:

\section{a. Metode Dokumentasi}

Dokumentasi berasal dari asal kata "Dokumen" yang artinya barang-barang tertulis. Didalam melaksanakan metode dokumentasi, peneliti menyelidiki benda-benda tertulis seperti buku notulen rapat, catatan harian, arsip dan sebagainya [19]. Metode dokumentasi adalah suatu metode pengambilan data dari sumbersumber yang tertulis baik berupa surat, foto, gambar, tabel, grafik maupun keterangan tertulis lainya.

Dari penguraian diatas dapat diketahui bahwa tehnik dokumentasi adalah suatu tehnik penelitian yang ditunjukan kepada penguraian dan penjelasan terhadap apa yang telah berlangsung melalui sumber-sumber dokumen dalam mengali suatu data. Metode dokumentasi di gunakan untuk meraih data-data seperti data jumlah siswa, jumlah guru, keadaan ruang, dan fasilitas belajar, serta data-data lain yang diperlukan dalam penelitian.

\section{b. Metode Tes}

Tes adalah suatu proses yang disegaja direncanakan untuk memperoleh informasi atau data, berdasarkan data tersebut mencoba membuat suatu keputusan [20].

Metode tes adalah alat prosedur yang di gunakan, alat ini berbentuk tugas-tugas yang dilaksanakan dan dapat berupa pertanyaan-pertanyaan atau soal-soal yang harus dijawab. Metode tes adalah suatu cara untuk mengadakan penilaian yang berbentuk tugas atau serangkaian tugas yang harus dikerjakan oleh siswa atau kempok anak sehingga menghasilkan suatu nilai tentang prilaku atau prestasi anak tersebut yang dibandingkan dengan nilai yang dicapai oleh anak lain atau standar yang ditetapkan [21].

Berdasarkan pendapat diatas metode tes adalah alat prosedur yang sistimatis yang berupa pertanyaan maupun tugas untuk mengadakan penilaian terhadap siswa atau kelompok anak sehingga menghasilkan suatu nilai tentang seberapa jauh perkembangan kualitas proses dan hasil belajar PKn siawa kelas VII SMP N 2 Gangga Kabupaten Lombok Utara.

Untuk memperoleh data seperti yang dimaksud, maka teknik atau metode yang akan digunakan dalam penelitian ini adalah metode tes, yakni tes awal (pre test) dan tes akhir (post test).

1) Tes Awal (Pre test)

Pretes ini dilakukan untuk mengetahui kemampuan awal kualitas proses dan hasil belajar siswa pada mata pelajaran PKn dari siswa sebelum memperoleh perlakuan. Butir soal tes diadaptasi dari buku penunjang PKn kelas VII kurikulum 2012 dengan bentuk soal objektif 25 butir. Pelajaran PKn disimak oleh siswa diadaptasi/disesuaikan dengan tujuan pembelajaran yang ditetapkan.

Pensekoran untuk setiap jawaban benar adalah 1 dan jawaban adalah o, sehingga skor maksimal 25 dan skor minimal o. Sebelum digunakan perangkat tes ini, telah dikonsul-tasikan dengan instruktur dan guru inti PKn.

2) Tes Akhir (Post test)

Tes hasil belajar PKn dilakukan untuk mengukur perolehan hasil belajar pada akhir pelajaran atau setelah memperoleh perlakuan. Butir soal tes diadaptasi dari soal yang disusun oleh MGMP (Musyawarah Guru Mata Pelajaran) berdasarkan silabus PKn semester 2 kelas VII D, dengan bentuk soal objektif 25 butir soal.

\section{Jenis dan Sumber Data}

\section{a. Jenis Data}

Jenis data dalam kajian penelitian menjadi sangat mendasar untuk diklarifikasikan mengingat masalah ini akan melandasi kegiatan selanjutnya. Pemahaman Jenis data adalah suatu hal yang mutlak dalam penelitian menurut [22], umumnya data terbagi atas Data kualitatif dan Data Kuantitatif.

1) Data Kualitatif jenis data yang berbentuk katakata, kalimat atau pendapat dari responden atau informan penelitian.

2) Data Kuantitatif adalah data yang berbentuk angka atau data kuantitatif yang dianggkakan (skoring) namun demikian, data dalam penelitian ini selalu dihubungkan dengan skala pengukurannya.

Menurut [12] skala pengukuran dapat berupa yaitu sebagai berikut :

a. Skala Nominal, disusun berdasarkan jenis atau kategori seperti : agama yang di anut : (1) islam, (2) hindu, (3) kristen, (4) budha dan lain-lain. 
b. Skala Ordinal, disusun berdasarkan rangking, seperti mengukur rengking dalam suatu pertandingan juara I, II, III.

c. Skala Interval, adalah skala yang menunjukan jarak antara satu dengan data yang lain mempunyai bobot yang sama,sepertti hasil belajar dari 1-100, indeks prestasi dari 1-4 dan lain-lain.

d. Skala Rasio, adalah skala pengukuran yang mempunyai nilai nol mutlak dan mempunyai jarak yang sama (merupakan bilangan yang sebenarnya), seperti ukuran panjang meter ada o meter dan lain-lain.

Adapun jenis data yang digunakan dalam penelitian ini adalah data Kuantitatif yang berskala Interval yaitu untuk mencari pembeda hasil belajar siswa antara sebelum dan sesudah penggunaan pembelajaran kooperatif model artikulasi.

\section{b. Sumber Data}

Sumber data dalam penelitian ini adalah sumber yang diperoleh dari subyek selama melakukan penelitian. Menurut [23], sumber data menurut sifatnya digolongkan menjadi 2 (dua) jenis yaitu sumber data primer dan sumber data sekunder.

1. Sumber data primer adalah sumber-sumber yang memberikan data lansung dari tangan pertama.

2. Sumber data sekunder adalah sumber mengutip dari sumber lain mencakup dokumen-dokumen resmi, buku-buku, hasil-hasil penelitian yang berwujud laporan.

Data primer dalam penelitian ini diperoleh dari hasil observasi dan wawancara. Sedangkan data sekunder diperoleh dari hasil pencatatan dokumentasi hasil penelitian.

\section{Identifikasi dan Definisi Operasional \\ Variabel \\ a. Identifikasi Variabel}

variabel adalah objek penelitian atau apa yang menjadi titik perhatian suatu penelitian [11], variabel merupakan suatu sifat atau nilai dari orang, subyek, atau kegiatan yang mempunyai variasi tertentu yang ditetapkan oleh peneliti [12]. Berdasarkan pendapat para ahli di atas dapat disimpulkan bahwa variabel merupakan suatu gejala atau objek yang akan diteliti dan menjadi suatu titik perhatian dalam penelitian dan merupakan suatu subjek atau kegiatan yang mempunyai variasi tertentu yang ditetapkan oleh peneliti.

Agar tidak menimbulkan kesimpangsiuran tentang variabel-variabel penelitian, maka perlu ditetapkan variabel-variabel penelitian. Dalam penelitian ini ada dua jenis variabel yaitu 1) Variabel bebas yaitu variabel yang mem-pengaruhi variabel lainya atau mengakibatkan variabel lainya berubah. 2) Variabel terikat yaitu variabel yang dipengaruhi oleh variabel bebas [24].

Dari peryataan diatas, maka dapat diambil kesimpulan bahwa variabel bebas dalam penelitian ini adalah Cooperative Learning model artikulasi, sedangkan variabel terikatnya adalah meningkat-kan hasil belajar siswa kelas VII Semester II SMP Negeri 2 Gangga.

\section{b. Definisi Operasional Variabel}

Analisis data merupakan proses yang merinci secara formal untuk menentukan tema dan merumuskan hipotesis seperti yang disarankan oleh data-data sebagai usaha untuk memberikan bantuan pada tema dan hipotesis [25].

Untuk menganalisa data berkaitan dengan tujuan penelitian pertama dan kedua yaitu untuk mengetahui ada tidaknya Peningkatan kualitas proses dan hasil belajar dengan menggunakan Cooperative Learning model artikulasi maka digunakan rumus pretes-posttes one group dari [11] sebagai berikut :

$$
t=\frac{M d}{\frac{\sqrt{\sum x^{2}} d}{N(N-1)}}
$$

Keterangan :

$\mathrm{t} \quad$ : Kode rumus t-tes

Md : Mean dari perbedaan pretes dengan posttes (pretes-posttes)

$\sum \mathrm{x}^{2} d$ : Jumlah kuadrat deviasi

xd : Deviasi masing-masing subjek (d-Md)

d.b : Ditentukan dengan (N-1)

$\mathrm{N}$ : Jumlah subjek pada sampel.

Alasan menggunaan rumus t-tes ini karena dalam penelitian ini, peneliti ingin membanding-kan hasil dari kedua variabel.

\section{HASIL DAN PEMBAHASAN}

Data dari hasil penelitian ini terdiri dari hasil belajar siswa sebelum menggunakan metode pembelajaran kooperatif learning model artikulasi dan hasil belajar siswa sesudah menggunakan metode pembelajaran kooperatif leraning model artikulasi.

Adapun data mengenai hasil belajar siswa sebelum menggunakan metode pembelajaran kooperatif leraning model artikulasi dapat dilihat pada tabel berikut:

Tabel 4

Data Hasil Belajar Siswa Kelas VII D SMP N 2 Gangga (Pre-test)

\begin{tabular}{clc}
\hline No & \multicolumn{1}{c}{ Nama Siswa } & $\begin{array}{c}\text { Nilai Hasil Belajar } \\
\text { Siswa } \\
\text { (pre-test / O })\end{array}$ \\
\hline 1 & Adi Suseno Putra & 60 \\
2 & Anggeraini Setiawati & 68 \\
3 & Anggi Rismayanti & 64 \\
4 & Aulia Eka Meliyanis & 72 \\
5 & Depi Maryani & 68 \\
6 & Eli & 64 \\
7 & Faisal Fahrozi & 68 \\
8 & Haris Jonaldi & 72 \\
9 & Heri Sastrawadi & 56 \\
10 & Ikhwan & 68 \\
11 & Ismawadi & 72 \\
12 & Lalu Dudung Hidayat & 76 \\
13 & Mardani & 64 \\
\hline
\end{tabular}


6 CIVICUS : Pendidikan-Penelitian-Pengabdian Pendidikan Pancasila dan Kewarganegaraan | Vol. 7, No. 1, Maret 2019, hal 1-8

\begin{tabular}{|c|c|c|}
\hline 14 & Mita Rosdiana & 68 \\
\hline 15 & Muhamamad Tobi & 72 \\
\hline 16 & Navi Janatun & 60 \\
\hline 17 & Nunung Ramdhani & 68 \\
\hline 18 & Pidia Ariningtias & 72 \\
\hline 19 & Rendi Zulhifan & 64 \\
\hline 20 & Riza Utami & 68 \\
\hline 21 & Roy Santori & 76 \\
\hline 22 & Serin Sapna Maulida & 64 \\
\hline 23 & Titin Patmawati & 68 \\
\hline \multirow[t]{2}{*}{24} & Wahyudin Hamid & 72 \\
\hline & $\mathrm{N}=24$ & $\begin{aligned} & =1624 \\
X_{1} & =67,67\end{aligned}$ \\
\hline
\end{tabular}

Sumber data dari rekapitulasi nilai Pre-test siswa kelas VII D.

Setelah diterapkan metode pembelajaran kooperatif model artikulasi pada siswa, peneliti melakukan evaluasi hasil belajar siswa. Data hasil evaluasi belajar siswa setelah menggunakan metode pembelajaran kooperatif model artikulasi adalah sebagai berikut:

Tabel 5

Data Hasil belajar siswa sesudah menggunakan metode pembelajaran Kooperatif model Artikulasi (Post-test)

\begin{tabular}{|c|c|c|}
\hline No & Nama Siswa & $\begin{array}{c}\text { Nilai Hasil Belajar } \\
\text { Siswa }\left(\text { Post-test } / \mathrm{O}_{2}\right)\end{array}$ \\
\hline 1 & Adi Suseno Putra & 72 \\
\hline 2 & Anggeraini Setiawati & 84 \\
\hline 3 & Anggi Rismayanti & 76 \\
\hline 4 & Aulia Eka Meliyanis & 88 \\
\hline 5 & Depi Maryani & 80 \\
\hline 6 & Eli & 76 \\
\hline 7 & Faisal Fahrozi & 72 \\
\hline 8 & Haris Jonaldi & 88 \\
\hline 9 & Heri Sastrawadi & 68 \\
\hline 10 & Ikhwan & 76 \\
\hline 11 & Ismawadi & 84 \\
\hline 12 & Lalu Dudung Hidayat & 84 \\
\hline 13 & Mardani & 80 \\
\hline 14 & Mita Rosdiana & 80 \\
\hline 15 & Muhamamad Tobi & 76 \\
\hline 16 & Navi Janatun & 68 \\
\hline 17 & Nunung Ramdhani & 76 \\
\hline 18 & Pidia Ariningtias & 80 \\
\hline 19 & Rendi Zulhifan & 68 \\
\hline 20 & Riza Utami & 72 \\
\hline 21 & Roy Santori & 88 \\
\hline 22 & Serin Sapna Maulida & 76 \\
\hline 23 & Titin Patmawati & 72 \\
\hline \multirow[t]{2}{*}{24} & Wahyudin Hamid & 80 \\
\hline & $\mathrm{N}=24$ & $\begin{array}{c}=1864 \\
X_{2}=77,67\end{array}$ \\
\hline
\end{tabular}

Sumber data dari rekapitulasi nilai Post-test siswa kelas X

Berdasarkan analisis data penulis akan menganalisis hubungan nilai hasil belajar siswa sebelum proses pembelajaran menggunakan metode Kooperatif model Artikulasi dengan nilai hasil belajar siswa sesudah menggunakan metode pembelajaran Kooperatif model Artikulasi. Untuk lebih jelasnya lihat pada tabel berikut ini:
Tabel 5

Tabel kerja nilai rata-rata hitung dari perbedaan Pretest dengan Post-test.

\begin{tabular}{|c|c|c|c|}
\hline $\begin{array}{l}\text { No } \\
\text { siswa }\end{array}$ & Pre-Test & Post-Test & $\begin{array}{c}\text { Gain (d) post-test pre- } \\
\text { test }\end{array}$ \\
\hline 1 & 2 & 3 & 4 \\
\hline 1 & 60 & 72 & +12 \\
\hline 2 & 68 & 84 & +16 \\
\hline 3 & 64 & 76 & +12 \\
\hline 4 & 72 & 88 & +16 \\
\hline 5 & 68 & 80 & +12 \\
\hline 6 & 64 & 76 & +12 \\
\hline 7 & 68 & 72 & +6 \\
\hline 8 & 72 & 88 & +16 \\
\hline 9 & 56 & 68 & +12 \\
\hline 10 & 68 & 76 & +8 \\
\hline 11 & 72 & 84 & +12 \\
\hline 12 & 76 & 84 & +8 \\
\hline 13 & 64 & 80 & +16 \\
\hline 14 & 68 & 80 & +12 \\
\hline 15 & 72 & 76 & +4 \\
\hline 16 & 60 & 68 & +8 \\
\hline 17 & 68 & 76 & +12 \\
\hline 18 & 72 & 80 & +8 \\
\hline 19 & 64 & 68 & +4 \\
\hline 20 & 68 & 72 & +4 \\
\hline 21 & 76 & 88 & +12 \\
\hline 22 & 64 & 76 & +12 \\
\hline 23 & 68 & 72 & +4 \\
\hline 24 & 72 & 80 & +8 \\
\hline $\mathrm{N}=24$ & $\begin{array}{l}=1624 \\
X_{1}= \\
67,67\end{array}$ & $\begin{array}{c}=1864 \\
X_{2}= \\
77,67\end{array}$ & $\sum d=246$ \\
\hline
\end{tabular}

Keterangan:

$$
\begin{array}{cl}
\mathrm{N}=24 & \\
\mathrm{X}_{1} & =67,67 \\
\mathrm{X}_{2} & =77,67 \\
\sum \mathrm{d} & =246
\end{array}
$$

Tabel 7

Cara menentukan $\mathrm{x}_{\mathrm{d}} \mathrm{dan} \mathrm{x}^{2} \mathrm{~d}$

\begin{tabular}{cccc}
\hline No. Siswa & $\mathrm{D}$ & $\begin{array}{c}\mathrm{x}_{\mathrm{d}} \\
(\mathrm{d}-\mathrm{Md})\end{array}$ & $\mathrm{x}_{\mathrm{d}}{ }^{2}$ \\
\hline $\mathbf{1}$ & $\mathbf{2}$ & $\mathbf{3}$ & $\mathbf{4}$ \\
1 & +12 & 1,75 & 3,06 \\
2 & +16 & 5,75 & 33,06 \\
3 & +12 & 1,75 & 3,06 \\
4 & +16 & 5,75 & 33,06 \\
5 & +12 & 1,75 & 3,06 \\
6 & +12 & 1,75 & 3,06 \\
7 & +6 & $-4,24$ & 17,98 \\
8 & +16 & 5,75 & 33,06 \\
9 & +12 & 1,75 & 3,06 \\
10 & +8 & $-2,25$ & 5,06 \\
11 & +12 & 1,75 & 3,06 \\
12 & +8 & $-2,25$ & 5,06 \\
13 & +16 & 5,75 & 33,06 \\
14 & +12 & 1,75 & 3,06 \\
15 & +4 & $-6,25$ & 39,06 \\
16 & +8 & $-2,25$ & 5,06 \\
17 & +12 & 1,75 & 3,06 \\
\hline
\end{tabular}




\begin{tabular}{cccc}
\hline 18 & +8 & $-2,25$ & 5,06 \\
19 & +4 & $-6,25$ & 39,06 \\
20 & +4 & $-6,25$ & 39,06 \\
21 & +12 & 1,75 & 3,06 \\
22 & +12 & 1,75 & 3,06 \\
23 & +4 & $-6,25$ & 39,06 \\
24 & +8 & $-2,25$ & 5,06 \\
\hline $\mathrm{N}=24$ & $\sum \mathrm{d}=246$ & & $\sum \mathrm{x}_{\mathrm{d}}^{2}=362,35$ \\
\hline
\end{tabular}

$\mathrm{Md}=\frac{\sum d}{N}=\frac{246}{24}=10,25$

Tes signifikasi untuk desain 2 adalah

$$
\begin{gathered}
\mathrm{t}=\frac{M d}{\sqrt{\frac{\sum \mathrm{x}^{2} \mathrm{~d}}{N(N-1)}}}=\frac{10,25}{\sqrt{\frac{362,35}{24(24-1)}}} \\
=\frac{10,25}{\sqrt{\frac{362,35}{24(23)}}}
\end{gathered}
$$$$
\begin{aligned}
& =\frac{10,25}{\sqrt{\frac{362,35}{552}}} \\
& =\frac{10,25}{\sqrt{0,66}} \\
& =\frac{10,25}{0,81}=12,64
\end{aligned}
$$

Sebelum peneliti menetapkan apakah hipotesis itu diterima atau ditolak, maka terlebih dahulu akan ditentukan derajat kebenaranya. Derajat kebenaran dapat ditentukan dengan rumus $\mathrm{db}=\mathrm{N}-1=24-1=23$ dengan taraf signifikasi $5 \%$, maka diperoleh bilangan dalam t-tabel sebesar $=2,069$.

Hal ini berarti hipotesis yang berbunyi "ada pengaruh penerapan metode pembelajaran kooperatif model artikulasi untuk meningkatkan kualitas proses dan hasil belajar PKn siswa kelas VIIdi SMP Negeri 2 Gangga Tahun Pelajaran 2012/2013”, diterima.

Dari hasil hitung data di atas dapat ditarik hasil analisa data seperti tercantum pada tabel berikut:

Tabel 8

Hasil Analisa Data Untuk Memperoleh Nilai t.

\begin{tabular}{ccccc}
\hline $\mathrm{X}_{1}$ & $\mathrm{X}_{2}$ & t-hitung & $\begin{array}{c}\text { Taraf } \\
\text { signifikan }\end{array}$ & t-tabel \\
67,67 & 77,67 & 12,64 & $5 \%$ & 2,069 \\
\hline
\end{tabular}

Dari hasil analisa data diperoleh nilai t-hitung $=12,64$ sedangkan $\mathrm{t}$-tabel pada taraf signifikasi $5 \%$ adalah 2,069. Dengan memperhatikan nilai t tersebut di atas, maka dapat dikatakan bahwa nilai t-hitung lebih besar dari pada t-tabel atau dapat dituliskan t-hitung = $12,64^{>}$t-tabel $=2,069$ ini berarti ada pengaruh yang signifikan terhadap penerapan metode pembelajaran Kooperatif model Artikulasi untuk meningkatkanhasil belajar PKn siswa Kelas VII semester II di SMP N 2 Gangga.

Berdasarkan hasil penelitian di atas dapat dikatakan bahwa hipotesis alternatif (Ha) yang diajukan dalam penelitian ini "diterima", sehingga dapat ditarik kesimpulan bahwa terdapat pengaruh yang signifikan terhadap penerapan metode pembelajaran Kooperatif model Artikulasi untuk meningkatkanhasil belajar PKn siswa Kelas VIIdi SMP N 2 Gangga.

Nilai rata-rata hasil belajar siswa yang diperoleh dengan menggunakan metode pembelajaran Kooperatif model Artikulasi sebesar 77,67 lebih tinggi dari rata-rata hasil belajar siswa sebelum menggunakan metode pembelajaran Kooperatif model Artikulasi yaitu sebesar 67,67. Hal ini berarti penerapan metode pembelajaran Kooperatif model Artikulasi dapat meningkatkan ratarata hasil belajar siswa sebesar 10,00.

\section{TEMUAN DAN DISKUSI}

Pembelajaraan kooperatif model artikulasi adalah Pembelajaran yang melatih siswa untuk tidak terlalu menggantungkan pada guru, akan tetapi dapat menambah kepercayaan kemampuan berpikir sendiri, dapat mengembangkan kemampuan mengungkapkan ide atau gagasan, dapat membantu anak untuk merespon orang lain, dapat memberdayakan siswa untuk lebih bertanggung jawab dalam belajar, dapat meningkatkan prestasi akademik sekaligus kemampuan sosial, dan dapat mengembangkan kemampuan siswa untuk mengukapkan pendapatnya dimuka umum [26].

Penggunaan metode pembelajaran Kooperatif model Artikulasi dapat meningkatkan hasil belajar dalam proses belajar mengajar. Hal ini ditunjukkan pada proses belajar mengajar dikelas dimana setiap siswa dengan aktif dan jeli dalam menyimak dan memperhatikan penjelasan terkait dengan materi yang disampaikan oleh guru kemudia siswa mencoba menangggapi dan maemahami apa yang telah disampaikan oleh guru dengan pengetahuan yang dimiliki sebelumnya dengan cara membuat catatancatatan kecil terkait intisari dari materi yang disampaikan kemudian siswa berdiskusi dengan pasangan atau teman satu kelompoknya dan membagi tugas dan memaparkan kembali terkait dengan materi yang telah disampaikan oleh guru yang kemudian dilanjutkan dengan Tanya jawab dengan kelompok lain dan diakhiri dengan siswa membuat kesimpulan dari materi yang telah dipaparkan.

Kegiatan belajar pada saat ini sangat dipengaruhi oleh faktor sekitar yang ada disekeliling kita terutama faktor pengganggu situasi belajar siswa terutama situasi di luar sekolah seperti situasi belajar di rumah. Dengan metode pembelajaran Kooperatif model Artikulasi memungkinkan siswa memanfaatkan setiap peluang untuk belajar dan mempersiapkan diri lebih 
baik dalam menerima pelajaran karena dengan metode pembelajaran Kooperatif model Artikulasi mudah digunakan sehingga siswa serta melatih siswa atau peserta didik dalam belajar berbicara atau menyampaikan pendapat mereka terkait dengan materi pelajaran yang sedang dibahas dan mampu merangsang kreatifitas dan daya tanggap siswa. Hal tersebut senada dengan penelitian lainnya yang menemukan bahwa pembelajaran model artikulasi merupakan model pembelajaran yang menuntut siswa aktif dalam pembelajaran siswa dibentuk menjadi kelompok kecil, masing-masing siswa dalam kelompok tersebut mempunyai tugas mewawancarai teman kelompoknya tentang materi yang baru dibahas[8]. Senada juga hasil penelitian lainnya menunjukkan bahwa penerapan model pembelajaran Artikulasi dapat meningkatkan hasil belajar siswa meningkat menjadi 70,57 dan 78,03 pada siklus II. Demikian juga dengan ketuntasan kelas (klasikal) mengalami peningkatan dari $33,33 \%$ pada sebelum tindakan menjadi $66,67 \%$ pada siklus I, dan akhirnya mencapai $100 \%$ pada siklus[27]. Jadi penerapan metode pembelajaran dengan menggunakan metode kooperatif model artikulasi dalam proses belajar mengajar, karena relatif mudah dan sangat simpel dalam pelaksanaanya serta memberikan peluang besar pada siswa untuk melatih daya tanggap dan kreatifitas siswa.

\section{E. SIMPULAN DAN SARAN}

Hasil penelitian menunjukkan bahwa penerapan metode pembelajarankooperatif model artikulasi dapat meningkatkan hasil belajar siswa kelas VIIdi SMP N 2 Gangga terbukti dari hasil analisis data menunjukkan bahwa t-hitung $12,64>2,069$ (t-tabel), selain itunilai rata-rata yang terdapat pada kedua kelompok tes yaitu kelompok siswa yang diberikan metode pembelajaran kooperatif model artikulasi sebesar 77,67 dan kelompok siswa yang tidak menggunakan metode pembelajaran kooperatif model artikulasi ketuntasan belajarnya sebesar 67,67. Maka dapat dikatakan hipotesis alternative (Ha) diterima yang berbunyi bahwa metode pembelajaran kooperatif model artikulasi dapat meningkatkan hasil belajar PKn siswa kelas VII di SMP N 2 Gangga.

Disaran kepada guru untuk menerapkan metode pembelajaran kooperatif model artikulasi karena sudah terbukti keber-hasilanya dalam meningkatkan hasil belajar. Mengembangkan penelitian metode pembelajaran dengan metode kooperatif model artikulasi supaya semakin memantapkan pelaksanaan pembelajaran dan dapat selalu meningkatkan hasil belajar siswa. Bagi Sekolah agar menyediakan sarana dan prasarana yang memadai agar tercipta kelancaran dalam proses kegiatan belajar mengajar baik di dalam kelas maupun di luar kelas.

\section{UCAPAN TERIMA KASIH}

Penulis mengucapkan terima kasih kepada ketua LPPM yang senantiasa memberikan dana dan semua pihak yang membantu memberikan data penelitian sehingga penelitian ini dapat diselesaikan tepat waktu sesuai yang direncanakan.

\section{DAFTAR RUJUKAN}

[1] S. Sagala, Kemampuan Profesional Guru dan Tenaga Kependidikan: Pemberdayaan guru, tenaga kependidikan, dan masyarakat dalam manajemen sekolah. Alfabeta, 2009.

[2] S. Sagala, "Konsep dan Makna Pembelajaran." Bandung: alfabeta, 2010.

[3] E. T. Wahyuni, "Peningkatan Hasil Belajar PKn Materi Organisasi melalui Model Numbered Head Together di Kelas V," Briliant J. Ris. dan Konseptual, vol. 2, no. 4, pp. 494-503, 2017.

[4] H. S. Kristanti, "Peningkatan Kecakapan Berkomunikasi Dan Hasil Belajar PKn Siswa Kelas 6 dengan Talking Stick Berbantuan Salindia," Sch. J. Pendidik. dan Kebud., vol. 8, no. 3, pp. 293-301, 2018.

[5] E. Mulyasa, "Kurikulum Berbasis Kompetensi (KBK)," Konsep, Karakteristik dan, 2004.

[6] O. Hamalik, Proses Belajar Mengajar. Bumi Aksara, 2004.

[7] N. Sudjana, "Dasar-dasar Proses Belajar Mengajar," VII, Bandung Sinar Baru algesindo, vol. 92, 2004.

[8] E. Sadjaah, "Layanan dan Latihan Artikulasi Bagi Anak Tunarungu." Bandung: San Grafika, 2003.

[9] H. Pese, H. A. Lamba, and M. Ali, "Penerapan Model Pembelajaran Kooperatif Tipe Artikulasi Untuk Meningkatkan Hasil Belajar Fisika Siswa Pada Kelas Viiib SMP Negeri 2 Marawola," JPFT (Jurnal Pendidik. Fis. Tadulako Online), vol. 1, no. 1, 2012.

[10] R. Rajuli, S. Utami, and M. Abdul, "Pengaruh Penerapan Model Artikulasi terhadap Hasil Belajar Pendidikan Kewarganegaraan di Sekolah Dasar," J. Pendidik. dan Pembelajaran, vol. 5, no. $2,2015$.

[11] A. Suharsimi, "Prosedur penelitian suatu pendekatan praktik," Jakarta: Rineka Cipta, 2006.

[12] K. Sundara, Metode Penelitian Pendidikan (Teori dan Aplikasi). Mataram: UM-Mataram, 2012.

[13] Y. Riyanto, "Metodologi Penelitian Pendidikan Kualitatif dan Kuantitatif." Surabaya: Unesa university press, 2007.

[14] S. Faisal, "Metodologi Penelitian Pendidikan," Surabaya Usaha Nas., 1982.

[15] Sugiyono, "Metode Penelitian kuantitatif kualitatif dan R dan D," Alf. Bandung, 2010.

[16] P. Amudi, "Pengantar Statistik," Ghalia Indones. Jakarta, 1975.

[17] M. B. A. Riduwan, "Skala Pengukuran Variabelvariabel Penelitian," Alf. Bandung, 2007.

[18] M. Nazir, "Metode Penelitian," Jakarta Ghalia Indones., 1988.

[19] A. Suharsimi, "Prosedur Penelitian, Jakarta: PT," Rineka Cipta, p. 201:274, 2013. 
[20] M. N. Purwanto, Prinsip-prinsip dan teknik evaluasi pengajaran. Remaja Rosdakarya, 2000.

[21] W. Nurkancana and P. P. N. Sunartana, "Evaluasi Hasil Belajar,” Surabaya Usaha Nas., 1990.

[22] S. Hadi, "Metodologi Penelitian Research jilid II." Yogyakarta: Andi Offset, 2002.

[23] B. Ashshofa, "Metode Penelitian Hukum, Jakarta.” Rineka Cipta, 2004.

[24] Sugiyono, Metode Penelitian Pendidikan:(Pendekatan Kuantitatif, Kualitatif dan $R \& D$ ). Alfabeta, 2014.

[25] L. J. Moleong, "Metodologi Penelitian Kualitatif,(Bandung: Remaja Rosdakarya, 2010), cet," Ke-13, $h$, vol. 111.

[26] A. Suprijono, "Model-model Pembelajaran Emansipatoris," Yogyakarta: Pustaka Pelajar, 2016.

[27] M. Sermatang, "Implementasi Model Pembelajaran Artikulasi Dalam Meningkatkan Hasil Belajar Siswa Pada Mata Pelajaran Ips Terpadu Di Kelas VIII SMP Negeri 1 Selaru Kabupaten Maluku Tenggara Barat," J. Pendidik. Ekon., vol. 3, no. 1, 2018. 